DOI: 10.20472/EFC.2019.011.001

\author{
AMINA AHMAD KWAIDO \\ Umaru Ali Shinkafi Polytechnic Sokoto, Nigeria., Nigeria
}

\title{
IMPACT OF ENTREPRENEURSHIP EDUCATION ON YOUTH UNEMPLOYMENT: A CASE OF UMMARU ALI SHINKAFI POLYTECHNIC SOKOTO, NIGERIA.
}

\begin{abstract}
:
Educational orientation of youths in Nigeria is white-collar job directed, which is one of the factors responsible for the youth unemployment in the country, because the educational system itself fails to empower the ones passing through it. To solve the problem of unemployment in this situation, there is need to reorient the youths to think of job creation away from the mindset of job seekers, by inculcating entrepreneurship skill into the youths and building their interests towards entrepreneurship, especially while they are still in school.

The study examined the strength of entrepreneurship education on impacting the right skills and attitudes to students and determined the extent to which students exposed to entrepreneurial education are willing to undertake the establishment of their own enterprises.

The methodology adopted was based on Descriptive survey design which relied on primary and secondary sources of gathering data, through the use of structured questionnaires. Two hundred (200) questionnaires were administered, and one hundred and fifty four (154) were returned. The study adopted simple random sampling technique. The data was analyzed and Presented using Descriptive statistics (frequencies, percentages) and chi-square was adopted to analyze data.

The study shows that entrepreneurial education in Ummaru Ali Shinkafi polytechnic is effective in imparting entrepreneurial skills and attitudes to students as well as building their interests towards establishing their own businesses.

The study recommends that tertiary institutions, government, parents and the international donors supporting higher education projects must work together to create an ecosystem of support including training, mentorship, and access to finance Start -up Capital should be provided through micro-finance banks and other specialized agencies to adequately empower young entrepreneurs. There is an urgent need for the government to provide an enabling environment in the forms of efficient and available basic infrastructural facilities.
\end{abstract}

\section{Keywords:}

Youth unemployment, Entrepreneurship, Entrepreneurship Education

JEL Classification: A23, A00, A19 


\section{Introduction}

Nigeria faces a major problem of graduate unemployment (Ojeagu, 2011). Young men and women leave the Universities, Polytechnics and Colleges of Education every year with little or no hope of securing jobs (Wikipedia, 2013). Available information by National Universities Commission (NUC, 2004) reiterates the massive unemployment of graduates in the country. NUC noted that the most significant factor that has complicated the problem of graduate unemployment is the mindset of the youth. The mindset of the youth can be changed favorably through entrepreneurship education, because entrepreneurship can empower, generate innovation and change mindsets (Garba, 2010). Thus, the capacity of the economy to absorb the products of an over expanding tertiary institutions can be achieved.

According to the Norwegian Agency for Development Cooperation (2010), in many developing countries youths with higher education, experiences unemployment. In the same vein, (Branson, 2010) noted that many Nigerian youths are wallowing in abject poverty. She lamented that government often cushions the effect of poverty on vulnerable groups by establishing vocational and technical schools with the objectives to impart employability skills and competences to youths and school leavers. This calls to mind the need for entrepreneurial development.

Furthermore, (Oviawe and Anavberokha, 2008) opine that if our graduates are properly harnessed through entrepreneurship skills, Nigeria will be transformed technologically, economically, industrially and socio-politically. By these attributes our youths will be adequately empowered to face the world of work and stand tall in the comity of nations.

\section{Problem Statement/Justification}

The youth unemployment is rapidly increasing in many developing countries as their economies and educational systems are unable to accommodate the growing number of youths. National bureau of statistics, (2009), Opined that Nigerian labour market could barely absorb $10 \%$ of the over 3.8 million persons turned out by the Nigeria educational system annually. Thus, youth unemployment is an urgent global issue that has repercussions in demographic, social, economic, health, and environmental spheres. These impacts will be felt at the individual, family, national and global levels if not addressed.

Nigeria with minimal welfare systems, unemployment equates to no income and therefore no food, no shelter, no medicine and none of the other basic necessities of life. This leading to desperation driving many youths into living outside the law both to survive and as a means of expressing dissatisfaction at the apparent neglect of their very existence. Notably this situation is a prelude for disasters like violence, crime and political instability, 
robbery, kidnapping, prostitution, human trafficking, child abuse and unfair labour practices experienced in Nigeria by the unemployed youths.

Youths bring with them boundless energy, imagination, creativity, ideals, and a limitless vision for their future and societies. If provided with an enabling environment and opportunities, youths in developing countries can be key agents for social change, economic development and technological innovation. If not utilized, they are a wasted resource. Thus, it is imperative that youth are harnessed as part of society. This can be achieved through inculcating entrepreneurship skill into them, especially while they are still in school. National planning commission (2005).

The problem of this study revolved around the high rate of unemployment and low productivity among the youths of Nigeria. The present situation seems to give an impression of economic insecurity as a result of failure to properly engage people in the production process. This study was therefore necessary to fill the gap by examining the entrepreneurial development and urgent social intervention for all government strategies/programmes to have employment generation as an output towards economic security. The question remains: given that the economy of Nigeria is producing below its potential, can entrepreneurship education and urgent social intervention guarantee high unemployment reduction?

\section{Objective of the Study}

To determine the extent to which students exposed to entrepreneurial education are willing to undertake the establishment of their own businesses.

Based on the Objective of the study, the following hypothesis is derived:

\section{Hypothesis}

$\mathbf{H}_{\mathrm{o}}$ : Participation in an entrepreneurship education programme does not favourably increases the probability of becoming an entrepreneur.

$\mathbf{H}_{\mathrm{i}}$ : Participation in an entrepreneurship education programme can favourably increases the probability of becoming an entrepreneur.

\section{Literature Review: Youth Unemployment}

Every economy is characterized by both active and inactive populations. The active populations are referred to as the population willing and able to work, and include those actively engaged in the production of goods and services, and the inactive population are those who are unemployed. Unemployment can be referred to as numbers of the economically active population who are without work but available for and seeking work, including people who have lost their jobs and those who have voluntarily left work (World Bank, 2001). According to Fajana (2000), unemployment refers to a situation where people who are willing and capable of working but are unable to find suitable paid 
employment. It is unfortunate that graduates who are qualified, willing and able to work cannot find a job and as such earn nothing. It is one of the macro-economic problems which every responsible government is expected to monitor and regulate. The higher the unemployment rate in an economy, the higher would be the poverty level and associated welfare challenges. Fajana (2000) and Wikipedia (2013) identified the following types of unemployment:

i. Structural unemployment occurs when there is a change in the structure of an industry or the economic activities of the country. This may be due to use of outdated technology, deficiency of capital resources in relation to their demand and the product or service is no longer in demand.

ii. Frictional Unemployment is caused by industrial friction in which jobs may exist, yet the workers may be unable to fill them either because they do not possess the necessary skill or because they are not aware of the existence of such jobs. The employable may remain unemployed on account of shortage of raw materials or mechanical defects in the working of plants. Therefore, the better the economy is doing, the lower this type of unemployment is likely to occur.

iii. Seasonal Unemployment is due to seasonal variations in the activities of particular industries caused by climatic changes, changes in fashions or by the inherent nature of such industries. In the tropical region, ice factories are less active in rainy season because demand for ice is low. Seasonal oriented industries are bound to give rise to seasonal unemployment.

iv. Cyclical or Keynesian unemployment is due to the operation of the business cycle. This is a situation whereby the demand for labour becomes deficient to supply. In other words, when the aggregate demand falls below the full employment level, it is not sufficient to purchase the full employment level of output. It is characterized by an economy wide shortage of jobs and last as long as the cyclical depression exists.

v. Technological Unemployment is caused by changes in the techniques of production. Hence a situation whereby man is replaced by machines. Technological changes are taking place constantly, leading to the increased mechanization of the production process. This naturally results in the displacement of labour and finally causing unemployment.

vi. Residual Unemployment is caused by personal factors such as old age, physical or mental disability, poor work attitudes and inadequate training.

Whatever the type and cause of unemployment, entrepreneurship is the answer. Youth's unemployment across Nigeria has reached a new height and is likely to climb further. The result of a survey carried out by the World bank in 2001 shows that persons aged 0-14 years constituted 39.6\%, those aged between $15-64$ (the economically active 
population), constituted $56.3 \%$, while those aged 65 years and above constituted $4.2 \%$ unemployment

Analysis of employment data, for the past years shows that the rate of new entrants into the labour market has not been uniform. The rate was on the increase from 2007 to 2009 but declined significantly from 2009 to 2010. The rate increased again from 2010 to 2011 . Within the year's period, there has been an average of about 1.8 million new entrants into the active labour market.

Youth unemployment has been increasing because most graduates lack relevant marketable skills. The Federal government recently acknowledged that about 80 percent of Nigeria's youths are unemployed while 10 percent are underemployed. According to the National Population Commission (NPC), (2010) the national unemployment rates for Nigeria between 2000 and 2009 showed that unemployed persons constituted $13.6 \%$ in $2001,12.6 \%$ in $2002,13.4 \%$ in $2004,13.7 \%$ in $2006,14.9 \%$ in 2008 , and $19.7 \%$ in 2009 .

\section{Entrepreneurship Education}

The word, entrepreneurship is derived from the French word "entreprendre" meaning to undertake" Thus entrepreneurship is commonly defined as the process of creating a business. In the same vein, an entrepreneur is defined as one that creates a business. As stated by Atakpa, (2011), although the creation of business is certainly an important facet of entrepreneurship, it is not the complete picture. It is also the characteristics of seeking opportunities, taking risks beyond security and having the tenacity to push an idea through to reality.

To capture the above perspective, several authors have attempted a comprehensive definition of an entrepreneur. According to Christenson, (1996) "Entrepreneurs are people who have the ability to see and evaluate business opportunities, to gather the necessary resources to take advantage of them and initiate appropriate action to ensure success". For Holt, (2005), "Entrepreneur is an innovator or developer who recognizes and seizes opportunities; convert these opportunities into workable/marketable ideas, add value through time, effort, money or skills, assures the risks of the competitive market-place to implement these ideas and realizes the reward from these efforts".

Entrepreneurship is the act of starting a company, arranging business deals and taking risks in order to make a profit through the education skills acquired. However, the operational definition of entrepreneurship is the willingness and ability of a person or persons to acquire educational skills to explore and exploit investment opportunities, establish and manage a successful business enterprise.

Public policy makers recognize the importance of entrepreneurship as promoter of economic development and hence support instruments like entrepreneurship education to increase entrepreneurial activity. 
National programmes have been developed for the purpose of increasing entrepreneurial activity through various reforms, but these have proven abortive. According to Matsushita, (2008), about 93 percent of scholars are of the opinion that entrepreneurial skill can be developed via education and training. Thus, the establishment of entrepreneurial education is seen as a possible measure to promote entrepreneurship.

According to Nwagwu, (2004), entrepreneurship education is "a programme or part of the programme that prepares individuals to undertake the formation and acquisition of smallbusiness". Entrepreneurship Development Programme/Education is a planned, systematic and sustained effort at inculcating and nurturing the entrepreneurial spirit among Nigerians so as to produce a pool of willing, able and successful entrepreneurs.

Entrepreneurial education is the purposeful intervention by an adult (the teacher) in the life of a learner to impact entrepreneurial qualities and skills to enable the learner to survive in the world of business (Ghosh, 2002). It aims at equipping learners with skills, knowledge and dispositions that can help them develop or implement innovative social or business plans (Weller, 1998).

According to Dewalt, (1998), research evidence from different sources seems to suggest that individuals attending entrepreneurship courses have a higher tendency to start their own business at some point in their career than those attending other courses. In the view of Alao, (2005), the skills traditionally taught in business schools are necessary but not sufficient to make a successful entrepreneur. While students need to develop their business skills and understanding, more attention is required for the development of their entrepreneurial skills, attributes and behaviour.

\section{The Role of Entrepreneurship in National Development}

Entrepreneurs have led and will continue to lead the economic revolution that has proved repeatedly to improve the standard of living for people everywhere, thus, the role of entrepreneurship in national development include the following; Ossai, (2005)

1. Economic Development:The profits made by entrepreneurs, payments for the various factors of production by the entrepreneur flow as an increase into the National Income. Increase Gross Domestic Products, National Income etc. help in improving the standard of living of the citizens of the country.

2. Employment Opportunities: Entrepreneurship results in the creation of small businesses. The labour intensive nature of small businesses enables them create more jobs than the big businesses.

3. Improvement in the Standard of Living through Innovation:The introduction of high quality goods and services has transformed our lives.

4. Reduction in Rural-urban Drifts: One of the primary objectives of promoting entrepreneurship in developing countries is to mitigate rural-urban drift syndrome. 
The migration of rural dwellers to cities in search of 'white-collar' jobs has resulted in congestion, high incidence of crimes, etc.

5. Development of Local Technological Base: The development of indigenous technological base in all countries of the world has been championed by native entrepreneurs; this will help in transferring the much needed technology needed for the rapid transformation of the country.

6. Conservation of Foreign Exchanges: This will result from reduced importation of machineries and equipment, raw materials and payment to foreign experts.

\section{Problems of Entrepreneurship Development in Nigeria}

As stated earlier, government after government has initiated programmes to aid entrepreneurship development in Nigeria. In spite of these attempts at encouraging entrepreneurship development, the under listed problems are specific to the Nigerian entrepreneurs (Kabir, 2006):

1. Lack of Trust by Nigerians: This has resulted in the rejection of "made in Nigeria" goods as inferior to the imported ones. The mentality that anything made in Nigeria is inferior has discouraged and forced many local entrepreneurs to go out of business.

2. Shortage and Inadequacy of Infrastructure Facilities: This to my mind is the greatest problem facing the Nigerian entrepreneur. It is no longer news that 59 years after independence, the supply of electricity is epileptic if non-existent, the roads are death-traps leading to loss of lives and properties.

3. Corruption: Since entrepreneurs have to deal with government officials from the Local Government to State Government and the Federal Government, the demand for gratification in forms of bribes, double taxation, etc. has brought frustration to many entrepreneurs.

4. Lack of Management Know-how Resulting in Inability to Apply Appropriate Managerial Concepts and Principles in Running the Affairs of the Business: This is usually manifested in poor financial control, weak marketing effort, failure to develop a strategic plan, uncontrolled growth, improper inventory control.

5. Inability to Make Entrepreneurial Transition: As the business grows from the craft to entrepreneurial stage, informal and unprofessional management will suffice. However, the advent of the professional stage(s) calls for the business to be managed on professional basis. This will see authority delegated, policies formulated and a formal structure of relationship established.

6. Unguided and Unrestricted Importation of Goods into the Country: The advent of globalization with its attendant liberalization and deregulation has forced the Nigerian government to remove restrictions on the importation of goods even 
when there is a local substitute or competing brand. The unguided implementation of globalization has strangled most businesses. This is because, these businesses use obsolete methods of production, and private sources of power and in the end, their product are inferior and cost higher than the imported ones.

\section{Methodology}

\section{Sample and sampling techniques}

The population of study comprises students of Ummaru Ali Shinkafi Polytechnic Sokoto State, Nigeria. The study focused on the impact of entrepreneurship education program to reduce youth unemployment. The instrument used in this study is questionnaire. The sample comprises the final year students who were taking part in an entrepreneurship education program. In total 154 students will serve as the sample size for this work. The researcher adopted random sampling method.

The purpose was to discover the various levels of entrepreneurial acumen developed by each student, in order to see if the students have a concept of business startups, development and growth in the line of profession he/she has chosen. And also to see the acumen developed as a direct result of the impact education delivered in the institution, external avenues or a combination of both. The usage of questionnaires helped to identify whether the undergraduates were taught or learned the art of starting small businesses in their areas of specialization, and also identify if they do have a background in entrepreneurial education. This helped to analyze if truly they are being prepared for what the economy has to offer them, whether they are being trained to see opportunities for business, and to carve out a niche for themselves.

PRE-TEST: The questionnaire was pre-tested to ensure that misleading questions capable of producing wrong information were avoided

\section{Techniques of Data Analysis}

The data obtained from the study is analyzed using both descriptive statistics like frequencies, percentages and chi-square so as to be able to test the relevant hypothesis raised in the work.

\section{Data Collection}

Basically, the source of data for this work is both primary and secondary sources. Observation and Questionnaire is the primary method. Observation enhances the quality of data collection by providing essential information needed to develop questionnaires and to evaluate data collected from the other methods. Observation involves not only observing their activities in different situations, but also interacting and engaging in their activities (Spradley1980). Data for this work was also derived from secondary sources. This includes previous research and analysis by scholars as well as journal articles that 
are related to the subject. 200 questionnaires were administered but 154 questionnaires were returned for analysis.

\section{Data Presentation and Analysis}

Table 1: Do you agree that present Entrepreneurship program covers both the theoretical and practical aspects of Entrepreneurship Education?

\begin{tabular}{|l|c|c|c|}
\hline \multicolumn{1}{|c|}{ Response } & Frequency & Percentage & Cumulative \% \\
\hline Strongly Agreed & 68 & 44.2 & 44.2 \\
\hline Agreed & 49 & 31.8 & 76 \\
\hline Undecided & 07 & 04.5 & 80.5 \\
\hline Disagreed & 16 & 10.4 & 90.9 \\
\hline Strongly Disagreed & 14 & 09.1 & 100 \\
\hline Total & $\mathbf{1 5 4}$ & $\mathbf{1 0 0}$ & $\mathbf{1 0 0}$ \\
\hline
\end{tabular}

Source: Field Survey, 2018.

On the topics covered in both theoretical and practical aspects of entrepreneurship education. Table 1 shows that about $76 \%$ of the students agreed that they have covered their syllabus in theory and practice. $4.5 \%$ are unsure of what they have covered and about $19.5 \%$ disagree to the completion of the whole syllabus.

Table 2: What is the main factor that will hinder your ability to set-up your business immediately after graduation?

\begin{tabular}{|l|c|c|c|}
\hline \multicolumn{1}{|c|}{ Factors } & Frequency & Percentage & Cumulative \% \\
\hline Start-up capital & 85 & 55.2 & 55.2 \\
\hline Desire to further Education & 31 & 20.1 & 75.3 \\
\hline Lack of interest & 13 & 08.4 & 83.7 \\
\hline Lack of motivation & 11 & 07.2 & 90.9 \\
\hline All of the above & 14 & 09.1 & 100 \\
\hline Total & $\mathbf{1 5 4}$ & $\mathbf{1 0 0}$ & $\mathbf{1 0 0}$ \\
\hline
\end{tabular}

Source: Field Survey, 2018.

The above table shows that 85 of the respondents representing $55.2 \%$ having problem of start-up capital. $20.1 \%$ of the respondents are having the desire to further their education 
as the major factor, $8.4 \%$ of the respondents lack the interest for any business venture. $7.2 \%$ of respondents lack the encouragement and motivation. While $9.1 \%$ are affected by almost all the listed factors.

Table3: Out of following skills and attitudes which do you suggest for the development of entrepreneurial success?

\begin{tabular}{|l|c|c|c|}
\hline \multicolumn{1}{|c|}{ Skills and Attitudes } & Frequency & Percentage & Cumulative \% \\
\hline Creativity and innovativeness & 10 & 06.5 & 06.5 \\
\hline Opportunity recognition & 15 & 09.7 & 16.3 \\
\hline Initiative taking ability & 10 & 06.5 & 22.8 \\
\hline Risk taking ability & 32 & 20.8 & 43.6 \\
\hline All of the above & 87 & 56.5 & 100 \\
\hline Total & $\mathbf{1 5 4}$ & $\mathbf{1 0 0}$ & $\mathbf{1 0 0}$ \\
\hline
\end{tabular}

Source: Field Survey, 2018.

The table shows that the greater percentage about $56.5 \%$ of the respondents believe that all the named skills and attitudes are important for the development of entrepreneurial success.

\section{Test of Hypothesis}

We use chi-square test to determine if two attributes are independent of each other.

$\mathbf{H}_{\mathbf{o}}$ : Participation in an entrepreneurship education programme does not favourably increase the probability of becoming an entrepreneur.

$\mathrm{H}_{\mathrm{i}}$ : Participation in an entrepreneurship education programme can favourably increase the probability of becoming an entrepreneur. 
Table 4: $\quad$ Observed and Expected Frequencies

\begin{tabular}{|c|c|c|c|c|c|c|}
\hline $\begin{array}{l}\text { Entrepreneurship } \\
\text { Education/Factors }\end{array}$ & $\begin{array}{l}\text { Strongly } \\
\text { Agreed }\end{array}$ & Agreed & $\begin{array}{l}\text { Undecide } \\
\text { d }\end{array}$ & $\begin{array}{c}\text { Disagree } \\
\text { d }\end{array}$ & $\begin{array}{c}\text { Strongly } \\
\text { Disagree } \\
\text { d }\end{array}$ & $\begin{array}{c}\text { Tota } \\
\text { I }\end{array}$ \\
\hline Capital & $\begin{array}{c}40 \\
(37.5)\end{array}$ & $\begin{array}{c}34 \\
(27.0)\end{array}$ & $\begin{array}{c}2 \\
(3.9)\end{array}$ & $\begin{array}{c}5 \\
(8.8)\end{array}$ & $\begin{array}{c}4 \\
(7.7)\end{array}$ & 85 \\
\hline $\begin{array}{l}\text { Desire to further } \\
\text { Education }\end{array}$ & $\begin{array}{c}10 \\
(13.7)\end{array}$ & $\begin{array}{c}12 \\
(9.9)\end{array}$ & $\begin{array}{c}2 \\
(1.4)\end{array}$ & $\begin{array}{c}4 \\
(3.2)\end{array}$ & $\begin{array}{c}3 \\
(2.8)\end{array}$ & 31 \\
\hline Lack of interest & $\begin{array}{c}6 \\
(5.7)\end{array}$ & $\begin{array}{c}1 \\
(1.4)\end{array}$ & $\begin{array}{c}1 \\
(0.6)\end{array}$ & $\begin{array}{c}3 \\
(1.4)\end{array}$ & $\begin{array}{c}2 \\
(1.2)\end{array}$ & 13 \\
\hline Lack of Motivation & $\begin{array}{c}5 \\
(4.9)\end{array}$ & $\begin{array}{c}1 \\
(3.5)\end{array}$ & $\begin{array}{c}1 \\
(0.5)\end{array}$ & $\begin{array}{c}2 \\
(1.1)\end{array}$ & $\begin{array}{c}2 \\
(1.0)\end{array}$ & 11 \\
\hline All of the above & $\begin{array}{c}7 \\
(6.2)\end{array}$ & $\begin{array}{c}1 \\
(4.5)\end{array}$ & $\begin{array}{c}1 \\
(0.6)\end{array}$ & $\begin{array}{c}2 \\
(1.5)\end{array}$ & $\begin{array}{c}3 \\
(1.3)\end{array}$ & 14 \\
\hline Total & 68 & 49 & 07 & 16 & 14 & 154 \\
\hline
\end{tabular}

Source: Field Survey, 2018.

Figures outside the brackets in the table above are observed frequencies $(O)$ while those in brackets are expected frequencies (E) The expected frequencies are calculated using the formula;

$E=\frac{R^{\top} C^{T}}{G^{\top}}$

Where: $\quad R^{\top}$ is the row total;

$\mathrm{C}^{\top}$ is the column total; and

$\mathrm{G}^{\top}$ is the grand total.

On comparing the observed frequencies $(O)$ and expected frequencies $(E)$, we will be able to calculate the chi-square values using the relation:

$X^{2}=\frac{(O-E)^{2}}{E}$ 
Table 5: $\quad$ Chi-Square Values

\begin{tabular}{|c|c|c|c|c|c|c|}
\hline $\begin{array}{l}\text { Entrepreneurshi } \\
\text { p education/ } \\
\text { Factors }\end{array}$ & $\begin{array}{l}\text { Strongly } \\
\text { Agreed }\end{array}$ & Agreed & $\begin{array}{l}\text { Undecide } \\
\text { d }\end{array}$ & $\begin{array}{c}\text { Disagree } \\
\text { d }\end{array}$ & $\begin{array}{c}\text { Strongly } \\
\text { Disagree } \\
\text { d }\end{array}$ & Total \\
\hline Capital & 0.2 & 1.8 & 0.9 & 1.6 & 1.8 & \\
\hline $\begin{array}{l}\text { Desire to further } \\
\text { Education }\end{array}$ & 1.0 & 0.4 & 0.3 & 0.2 & 0.0 & \\
\hline Lack of interest & 0.0 & 2.3 & 0.2 & 1.8 & 0.5 & \\
\hline $\begin{array}{ll}\text { Lack } & \text { Of } \\
\text { Motivation } & \end{array}$ & 0.0 & 1.8 & 0.5 & 0.7 & 1.0 & \\
\hline ALL & 0.1 & 2.7 & 0.3 & 0.2 & 2.2 & \\
\hline Total & & & & & & 22.5 \\
\hline
\end{tabular}

Source: Field Survey, 2018.

Since our contingency table above (Chi-Square table 5) has 5 rows and 5 columns, the appropriate Degrees of freedom $=(r-1)(c-1)$

$$
\begin{aligned}
& =(5-1)(5-1)=4 \times 4 \\
& =16
\end{aligned}
$$

We wish to test the null hypothesis at the 0.05 level of significance, the chi-square table value is $X^{2} 0.05,16=26.30$

\section{Decision Rule}

Reject $H_{0}$ if $X^{2} 0.05,16>X^{2}$ or otherwise.

That is $26.30>22.5$

We reject our $\mathrm{H}_{0}$ and conclude Participation in an entrepreneurship education programme can favourably increase the probability of becoming an entrepreneur.

\section{Conclusion}

This research study provides evidence of the link between entrepreneurial education and becoming self-employed. The belief is that when students are exposed to the concepts, principles and theories of entrepreneurship, they develop the confidence that a successful application of these will enable them succeed in business and to ginger them into thinking of how to create jobs for others instead of being job seekers. Entrepreneurship education in our institutions will to a great extent, assist in solving the problems of high unemployment. Any country left behind in this race will remain perpetually underdeveloped. However, the environment plays an important role in putting readiness into action or reality. 


\section{Recommendations}

It is recommended that tertiary institutions, government, parents and the international donors supporting higher education projects must work together to create an ecosystem of support including training, mentorship, and access to finance. Start -up Capital should be provided through micro-finance banks and other specialized agencies to adequately empower young entrepreneurs. There is an urgent need for the government to provide an enabling environment in the forms of efficient and available basic infrastructural facilities.

\section{References}

Alao O. (2005) Principles of Economics: Macro. Darkol Press and Publishers, Isolo, Lagos.

Atakpa, R.A (2011) Entrepreneurship Education: A Sine Qua-non in Business Education in Nigeria. Book of Readings, Association of Business Educators of Nigeria (ABEN) 1(11)

Branson, C. (2010) Tips for Entrepreneurial Success. Sunday Punch, July, 18.

Christenson, S. (1996). Keeping Taps on Youths. The Link College of Education and Human Resources,University of Minnesota.

Dewalt, K. M., Billie R.D., and Coral B. W. (1998) Participant Observation. InHandbook of Methods in Cultural Anthropology. H. Russell Bernard, ed. Pp. 259-299. Walnut Creek: AltaMira Press.

Fajana S. (2000). Functioning of the Nigerian Labour Market, Labonfin and Company,Lagos.

Garba, A.S (2010) Refocusing Education System towards Entrepreneurship Development in Nigeria: ATool for Poverty Eradication. European Journal of Social Sciences is (1) Retired (2010 from www.eurojornals.com/ejssis-1-13.pdf.

Ghosh, J. (2002); "Economic Empowerment of Women. Paper Presented at U.N Economic and Social Commission for Asia and the Pacific Conference.

Holt, D. H. (2005): Entrepreneurship New Venture Creation Prentice-Hall of India New Delhi.

International Labour Organization (2007). Global Employment Tends for Youths, Geneva.

Kabir, M. S (2006): Improving Indigenous Entrepreneur's Response to Industry Incentives in Sokoto State. M.Sc. (Economics) Dissertation Usmanu Danfodiyo University, Sokoto.

Matsushita, M. (2008) State of Industrialization Forecloses Vision 20:2020 Attainment. Lagos Financial Standard 9(287).

National bureau of statistics (2009). Statistical new: Labour force statistic No. 476: The NBS

National Population Commission (2010). Population Data in Nigeria.

National planning commission (2005). National economic empowerment and development strategy ( NEEDS) reprinted by CBN.

National University Commission (2004). Labour Market Expectations of Nigerian Graduates. Abuja: Education Trust Fund (ETF) 
Norwegian Agency for Development Cooperation (2010) Technical and Vocational Education andTraining. http://www.norad.no/en/Thematic+areas/Education/from+childhood-to-adulthoodtechnical+and+vocational+Educationand +Training. 151129.CMS. Retrieved (12/8/09)

Nwagwu, J.U. (2004) Alleviating Poverty through Vocational Education: The Nigerian Experience. Facultyof Education Imo State University, Owerri. http://www.gla.uk/centresCradalldocs BotswanapapersNIVAGIVL paper-61.pdf Retired 23/9/2009.

Ojeagu, I.J. and Owolabi, J.I. (2011) Entrepreneurship Education as a Panacea for ReducingUnemployment and Poverty Among Business Education Graduates. Book of Readings, Association ofBusiness Educators of Nigeria (ABEN) 1(11).

Oladele P.O, Akeke I. andOladunjoye O. (2011) Entrepreneurship Development: A Panacea forUnemployment Reduction in Nigeria. Journal of Emerging Trends inEconomics and Management Sciences (JETEMS) 2 (4): 251-256

Ossai, (2008) Entrepreneurs and entrepreneurship in Nigeria Lagos: Gold land business co. L.t.d.

Oviawe, J.I. and Anarberokhai, M.O. (2008) The Role of Entrepreneurship Education in the Realization ofthe National Economic Empowerment and Development Strategy (NEEDS). Technical andVocational Education Journal 1(1) pp. 57-65.

Spradley, J. P. (1980) Participant Observation. New York: Holt, Rinehart and Winston.

Weller, S. C. (1998) Structured Interviewing and Questionnaire Construction. In Handbook of Methods in Cultural Anthropology. H. Russell Bernard, ed. Pp. 365-409. Walnut Creek: Alta Mira Press.

Wikipedia (2013) Youth Empowerment. Last modified on 12th April, 2013

World Bank (2001): A diagnostic Review of the Small and Medium Scale Enterprise Sector (Interim Report), Nigeria. 